\title{
MOISTURE CONTENT, IGNITABILITY, AND FIRE RISK OF VEGETATION IN VERTICAL GREENERY SYSTEMS
}

\author{
Kalani C. Dahanayake and Cheuk Lun Chow* \\ Department of Architecture and Civil Engineering, City University of Hong Kong, \\ 83, Tat Chee Avenue, Kowloon Tong, Hong Kong, China \\ *Corresponding author: Tel.: +852 98330629; e-mail: cheuchow@cityu.edu.hk
}

RESUMEN

\begin{abstract}
Vertical greenery systems (VGS) are getting popular as a green cladding material. However, they have not been adequately assessed in terms of fire safety. Lack of maintenance and improper irrigation systems will cause drying of plants in VGS, creating substantial fire risk. Dry plants may be easily ignited and intensify the vertical spread of fire. However, potential fire hazards of VGS are barely discussed in the existing literature. The moisture content (MC) of a plant is one of the most critical factors affecting its ignitability. This study explores ignitability and fire risk of plants under radiative heat flux at different MCs. Three commonly used plant species for VGS - namely, Hedera helix Lowe, Peperomia obtusifolia (L.) A.Dietr., and Aglaonema commutatum Schott (the cultivar Lady Valentine)-were selected for study. These plants were subjected to natural drying under ambient conditions without water supply to simulate the plants in VGS without proper irrigation. The MC of the plants was measured and cone calorimeter testing was performed at different time intervals during their drying process. Ignition, heat release, and gaseous emissions were studied under radiative heat flux.
\end{abstract}

Los sistemas de barreras vegetales verticales cortafuegos (BVVC, o VGS por sus siglas en inglés), se están haciendo populares como "cortafuegos verdes." Estos sistemas, sin embargo, no han sido lo suficientemente evaluados en términos de seguridad contra incendios. La falta de mantenimiento y sistemas de irrigación inadecuados causan el desecamiento de las plantas en estos BVVC, creando un incremento sustancial en el riesgo de incendios. Las plantas secas pueden arder fácilmente e intensificar la propagación vertical del fuego. Sin embargo, el riesgo potencial de incendios en los BVVC ha sido muy poco debatido en la literatura existente. El contenido de humedad $(\mathrm{CH})$ en una planta es uno de los factores más críticos que afectan a su capacidad de ignición. Este estudio explora la ignición y el riesgo de incendio de plantas bajo diferentes flujos de calor radiante y $\mathrm{CH}$. Tres especies de plantas comúnmente usadas como BVVC - Hedera helix Lowe, Peperomia obtusifolia (L.) A.Dietr., y Aglaonema commutatum Schott (cultivar Lady Valentine)-fueron seleccionadas para este estudio. Estas plantas fueron sujetas a secado natural bajo condiciones ambientales normales sin riego adicional para simular las plantas usadas en BVVC sin la apropiada irrigación. El $\mathrm{CH}$ de las plantas fue medido y luego diferentes variables determinadas en un cono calorimétrico a diferentes intervalos de tiempo durante el proceso de secado. El tiempo de ignición, el calor liberado, y las emisiones de gases fueron estudiados bajo dis- 
When the plants were fresh and green, no ignition was observed for all three species. Hedera helix started to ignite once MC was lower than $243 \%$, at a heat flux of $50 \mathrm{~kW} \mathrm{~m}^{-2}$. Peperomia obtusifolia began to ignite once $\mathrm{MC}$ dropped below $200 \%$, at a heat flux of $20 \mathrm{~kW} \mathrm{~m}^{-2}$. Aglaonema commutatum ignition occurred once MC was lower than $316 \%$, at a heat flux of 50 $\mathrm{kW} \mathrm{m} \mathrm{m}^{-2}$. Cone calorimeter test data were used for analyzing the three key parameters: flashover propensity, total heat release per unit area, and smoke toxicity hazard. Analysis showed that low MC creates a high risk of flashover. Thermal risk and smoke toxicity hazard also increased at lower MC, but the risk was low for the three plants tested. These findings demonstrate the importance of maintaining healthy live plants to ensure that fire risk of VGS is minimal. This study provides good direction for assessing and understanding the fire behavior of vegetation in VGS. tintos flujos de calor radiante. Cuando las plantas estaban vivas y verdes, no hubo ignición en ninguna de estas tres especies. Hedera helix comenzó su ignición cuando su $\mathrm{CH}$ fue menor a $243 \%$, bajo un flujo de calor de $50 \mathrm{~kW} \mathrm{~m}^{-2}$. $P e-$ peromia obtusifolia comenzó su ignición cuando su $\mathrm{CH}$ descendió por debajo del $200 \%$, con un flujo de calor de $20 \mathrm{~kW} \mathrm{~m}^{-2}$. La ignición de Aglaonema commutatum ocurrió cuando su $\mathrm{CH}$ fue menor a $316 \%$, con un flujo de calor de 50 $\mathrm{kW} \mathrm{m}^{-2}$. Los datos obtenidos del cono calorimétrico fueron usados para analizar tres parámetros claves: la propensión a una combustión súbita generalizada, el calor total liberado por unidad de área, y el peligro de toxicidad por humo. El análisis mostró que bajos niveles de $\mathrm{CH}$ crean un alto riesgo de combustión súbita. El riesgo térmico y el peligro de toxicidad por humo se incrementa a bajos $\mathrm{CH}$, pero ese riesgo fue bajo para las tres especies analizadas. Estos hallazgos demuestran la importancia de mantener plantas vivas y saludables para asegurar que el riesgo de incendios en BVVC sea mínimo. Este estudio provee de buenas directrices para determinar y comprender el comportamiento de incendios de vegetación en BVVC.

Keywords: cone calorimeter, fire hazard, ignition, moisture content, vegetation, vertical greenery systems, VGS

Citation: Dahanayake, K.C., and C.L. Chow. 2018. Moisture content, ignitability, and fire risk of vegetation in vertical greenery systems. Fire Ecology 14(1): 125-142. doi: 10.4996/ fireecology. 140112514

\section{INTRODUCTION}

\section{VGS and Fire}

A vertical greenery system (VGS) is a wall partially or completely covered by vegetation. A traditional VGS uses a building facade as the media for growing or supporting vegetation. The modern VGS uses separate structural systems and artificial growing mediums to support plants.

Over the past decades, vertical greenery systems have evolved into a viable design component that can provide multiple benefits and aesthetic value to a wide variety of projects. They create a good opportunity to enhance the greenery cover in congested urban settings (Dahanayake and Chow 2015, 2017). Rapid development of cities has converted naturally vegetated areas into concrete jungles. Therefore, identifying innovative methods to integrate nature into modern cities is important in alleviating the adverse effects of urbanization. Historically, climbing plants were used in building facades for horticultural or ornamental purposes. Over the past years, VGS 
have undergone a significant development with the incorporation of new materials and structural attachments. Modern VGS such as modular living walls and hydroponic systems are faster to construct and can be installed at higher building elevations (Dahanayake and Chow 2017).

Vertical greenery systems have a great potential to enhance the biodiversity and ecological restoration in urban areas. They can accommodate a large diversity of plants including climbers, shrubs, groundcovers, succulents, and ferns, and they enhance visual richness and human wellbeing. Restorative effects of plants provide health benefits and help in releasing stress. Vertical greenery systems provide a good solution for urban heat island effect as vegetated surfaces greatly contribute in reducing the exterior surface temperature of building facades (Morakinyo et al. 2017). They also contribute to improving air quality by trapping gaseous pollutants and minimizing greenhouse gas emissions, and the vegetation helps to control sound pollution in urban areas. They also provide opportunity to gain agricultural benefits with edible plants and herbs (Dahanayake and Chow 2015).

However, the fire safety issues of these greenery features have not been assessed properly (Chow and Chow 2003, Lau et al. 2016). There is an emergent anxiety that VGS may constitute fire hazards (Department for Communities and Local Government London 2013), although the general consensus is that a VGS could hardly be ignited as long as it is kept green and alive (Knez 2014). Inadequate irrigation may dry the plants, creating a condition favorable for fire. A dry VGS may act as combustible cladding, which could be intensified by flammable materials such as oils, resins, waxes, and excess litter in the VGS. Moreover, poorly maintained vegetation may eventually become overgrown, thus creating a fuel ladder, causing fire spread to upper floors. Furthermore, it may contribute to fire spread from one building to the other. Conversely, a dry VGS may easily catch fire. An ignited VGS may even interrupt the exit of a building's occupants or entry of fire fighters during a fire incident.

Fire records for exterior wall fires with VGS show that fires can be very serious (White et al. 2014), as reported in a fire incident in Frankfurt, Germany, in a residential building. The fire spread throughout the wall, along the climbing plants, up to the neighboring property (Brandwein 2014). Another incident reported fire in a semi-enclosed beer garden in August 2012 in Sydney, Australia, where ferns in VGS caught fire from a candle. The VGS in this fire incident was hand-watered, without a proper irrigation system. Furthermore, some synthetic plants were also integrated into this green wall (McNeilage 2012). These fire incidents highlight the importance of understanding fire hazards and taking necessary precautions to minimize fire hazards of VGS. To identify necessary precautions for fire hazards, ignition and fire propagation in VGS should be adequately studied. Thus, the aim of this study was to explore the ignitability of vegetation used in VGS and the potential fire hazards. The fire behavior of vegetation largely depends upon the amount of fuel present and its moisture content (MC; Graham and McCarthy 2006). Since the MC of vegetation is the most critical parameter affecting ignition, this study explored MC and its effect on the ignitability of vegetation in detail.

\section{Moisture Content of Vegetation}

MC is considered to be the most critical factor that affects the ignitability of vegetation (Livingston and Varner 2016). It also impacts fire propagation (Qi et al. 2012). Therefore, it becomes an essential indicator in fire risk analysis (Jurdao et al. 2012). Vegetation moisture acts as a heat sink since heat is used to evaporate water. Moreover, it dilutes flammable volatiles and partially blocks air supply for 
combustion (Nelson 2001). Estimation of the $\mathrm{MC}$ of vegetation is one of the most challenging tasks to address in fire-risk rating, since water interactions with plants are complex and difficult to generalize (Chuvieco et al. 2004). $\mathrm{MC}$ is commonly computed by dividing the difference between wet mass $\left(M_{\text {spec }}\right)$ and dry mass $\left(M_{\text {dry }}\right)$ by the dry mass, and is expressed as a percentage. In fact, it is not an instantly measurable quantity since obtaining the dry mass requires oven drying of the specimen (Chuvieco et al. 2004, Jurdao et al. 2012). Usually dry mass can be obtained by oven drying of the specimen overnight until the mass becomes constant (heating to dry mass; McAllister et al. 2012). In this study, MC was calculated using Equation 1, in which dry mass has been obtained by oven drying $\left(70^{\circ} \mathrm{C}\right.$ overnight; Jurdao et al. 2012):

$$
M C=\frac{M_{\mathrm{spec}}-M_{\mathrm{dry}}}{M_{\mathrm{dry}}} \times 100
$$

To study the impact of MC on the fire behavior of VGS, specimens of decreasing MCs will need to be prepared to simulate the vegetation under different environmental conditions. In most of the literature, different MC of plant specimens was obtained by natural drying through air or using elevated temperatures for drying ( McAllister et al. 2012, Santoni et al. 2015). The natural drying method was selected in this study, as it replicates the drying process of plants due to improper irrigation of VGS.

\section{Using the Cone Calorimeter for Studying Fire Risk of VGS}

The cone calorimeter has been commonly used in assessing the fire behavior of materials such as pyrolysis (process by which material is decomposed into simpler molecular compounds due to the effects of heat), ignition, combustibility, heat release rate, fire spread, and so on. It is a widely accepted performance-based bench scale fire testing apparatus (ISO 1993, ASTM 2017). It utilizes the oxygen consumption principle and is accepted as the most suitable tool for heat release rate measurements. Pilot ignition is provided through a spark igniter. A specimen of dimensions up to $100 \mathrm{~mm} \times 100 \mathrm{~mm}$ can be tested under constant uniform heat flux (up to $100 \mathrm{~kW}$ $\mathrm{m}^{-2}$ ).

The transient heat release rate per unit area at time $t\left(Q(t), \mathrm{kW} \mathrm{m} \mathrm{m}^{-2}\right)$, ignition time (TTI, s), burning duration $\left(t_{\mathrm{B}}, \mathrm{s}\right)$, percentage mass loss of specimen $\left(m_{L}, \%\right)$, mass loss rate (MLR, $\mathrm{g} \mathrm{s}^{-1}$ ), peak heat release per unit area (pkHRR, $\mathrm{kW} \mathrm{m}^{-2}$ ), effective heat of combustion (EHC, MJ kg-1) (Petrella 1994, Babrauskas 1997) are some of the most important parameters resulting from cone calorimeter testing. The total heat release (THR, $\mathrm{MJ} \mathrm{m}^{-2}$ ) is obtained from transient heat release rate using Equation 2:

$$
T H R=\int_{0}^{t_{\mathrm{B}}} Q(t) d t .
$$

Once the specimen is burning, exhaust gases are used to analyze the gaseous products of combustion (Weise et al. 2005). Burning of vegetation emits carbon dioxide $\left(\mathrm{CO}_{2}\right)$ and other greenhouse gases (Bertolin et al. 2015). Gaseous concentrations of carbon dioxide $\left(\left[\mathrm{CO}_{2}\right], \%\right)$ and carbon monoxide ([CO], ppm) are used to understand the toxic hazard created by a particular material in combustion (Fateh et al. 2016). Measurements such as the specific extinction area of smoke (SEA, a measure of smoke obscuration potential per unit mass burned, $\mathrm{m}^{2} \mathrm{~kg}^{-1}$ ), rate of smoke release (RSR, $\left.\mathrm{m}^{-2} \mathrm{~s}^{-1}\right)$ and total smoke release (TSR, $\mathrm{m}^{3} \mathrm{~m}^{-2}$ ) are used to assess the smoke emission of materials.

Some of the pioneering studies based on ignitability of wood were performed using the cone calorimeter. Ignitability and fire hazard parameters measured in these studies included transient heat release rate, ignition time, mass 
loss rate, effective heat of combustion, smoke production, and concentrations of $\mathrm{CO}$ and $\mathrm{CO}_{2}$. These measurements were used to obtain the fire properties of wood, such as conductivity of unpyrolyzed material, thermal capacity of unpyrolyzed material, density of unpyrolyzed material, ignition temperature, latent heat of pyrolysis, density of char, char conductivity, and so on.

A few studies related to wildland fires and ornamental vegetation have also used the cone calorimeter in studying the fire behavior of vegetation (Table 1). The main focus of these studies included understanding the ignitability, fire resistivity, combustion properties, and gaseous emissions of different plant species.

Tested fuel specimens included fresh foliage with leaves and twigs (Liu et al. 2013) as well as dry forest litter (Santoni et al. 2015, Fateh et al. 2016). In fact, in most cases, forest litter had been oven dried before testing to minimize the effect of variations in MC (Santoni et al. 2015). Fresh foliage as well as oven-dried specimens of foliage have been tested in studies in which the effect of MC is a focus (White et al. 2002, Weise et al. 2005).

Table 1. Summary of previous study findings related to cone calorimeter experiments on vegetation. $\mathrm{pk}[\mathrm{HRR}]=$ peak heat release rate per unit area, $\mathrm{HRR}=$ heat release rate per unit area, EHC $=$ effective heat of combustion, TTI $=$ ignition time, $\mathrm{MLR}=$ mass loss rate, $\mathrm{THR}=$ total heat release, $\mathrm{CO}=$ carbon monoxide, $\mathrm{CO}_{2}=$ carbon dioxide, $\mathrm{SEA}=$ specific extinction area, $\mathrm{RSR}=$ rate of smoke release, $\mathrm{TSR}=$ total smoke release, $\mathrm{SPR}=$ smoke production rate.

\begin{tabular}{|c|c|c|c|c|c|}
\hline \multirow{3}{*}{ 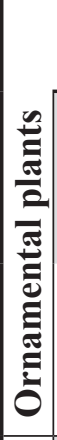 } & Reference & Study objective & $\begin{array}{l}\text { Specimen } \\
\text { description }\end{array}$ & $\begin{array}{c}\text { Important } \\
\text { parameters }\end{array}$ & Study outcome \\
\hline & Weise et al. 2005 & $\begin{array}{l}\text { Seasonal differences } \\
\text { in combustion } \\
\text { characteristics of } \\
\text { plants }\end{array}$ & $\begin{array}{l}\text { Foliage and small } \\
\text { branches of both } \\
\text { green and oven } \\
\text { dried specimens }\end{array}$ & $\begin{array}{l}\text { pk[HRR], HRR, } \\
\text { EHC, TTI, MLR }\end{array}$ & $\begin{array}{c}\text { Relative } \\
\text { ignitability of } \\
\text { different species }\end{array}$ \\
\hline & White et al. 1997 & $\begin{array}{l}\text { Flammability of } \\
\text { Christmas trees and } \\
\text { other vegetation }\end{array}$ & Fresh foliage & $\begin{array}{l}\text { pk[HRR], HRR, } \\
\text { EHC, TTI, MLR }\end{array}$ & $\begin{array}{l}\text { With natural } \\
\text { moisture, it is } \\
\text { very difficult to } \\
\text { sustain a flame }\end{array}$ \\
\hline \multirow{5}{*}{ 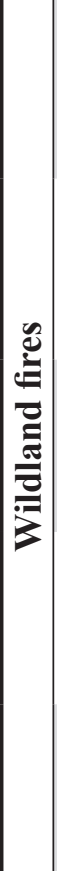 } & Liu et al. 2013 & $\begin{array}{c}\text { Combustibility of } \\
\text { fresh leaves of forest } \\
\text { species }\end{array}$ & Fresh foliage & $\begin{array}{l}\text { TTI, HRR, pk[HRR], } \\
\text { THR, }[\mathrm{CO}],\left[\mathrm{CO}_{2}\right], \\
\text { MLR, EHC, SEA, } \\
\text { THR, RSR, TSR }\end{array}$ & $\begin{array}{l}\text { Recommended } \\
\text { fire-resistant tree } \\
\text { species }\end{array}$ \\
\hline & Fateh et al. 2016 & $\begin{array}{c}\text { Burning behavior and } \\
\text { gaseous emissions } \\
\text { of Mediterranean } \\
\text { vegetation }\end{array}$ & Pine needles & $\begin{array}{l}\text { Yields of gaseous } \\
\text { emissions, MLR, TTI }\end{array}$ & $\begin{array}{l}\mathrm{CO}_{2} \text { and water } \\
\text { are the main } \\
\text { emissions }\end{array}$ \\
\hline & White et al. 2002 & $\begin{array}{l}\text { Measured the relative } \\
\text { flammability of } \\
\text { different plant species }\end{array}$ & $\begin{array}{l}\text { Green and dried } \\
\text { plant specimens }\end{array}$ & $\begin{array}{c}\text { HRR, pk[HRR], } \\
\text { EHC }\end{array}$ & $\begin{array}{c}\text { Some species } \\
\text { show higher } \\
\text { flammability than } \\
\text { others }\end{array}$ \\
\hline & Dibble et al. 2007 & $\begin{array}{c}\text { Combustion } \\
\text { characteristics of } \\
\text { northeastern USA } \\
\text { vegetation }\end{array}$ & $\begin{array}{l}\text { Fresh specimens } \\
\text { of foliage and } \\
\text { twigs }\end{array}$ & $\begin{array}{l}\text { HRR, pk[HRR], } \\
\text { THR, EHC }\end{array}$ & $\begin{array}{l}\text { Comparison } \\
\text { of combustion } \\
\text { properties among } \\
\text { many species }\end{array}$ \\
\hline & Santoni et al. 2015 & $\begin{array}{l}\text { Scale effect of testing } \\
\text { vegetation }\end{array}$ & Pine needles & $\begin{array}{l}\text { HRR, SPR, [CO], } \\
{\left[\mathrm{CO}_{2}\right], \mathrm{MLR}, \mathrm{SEA},} \\
\text { THR, RSR, TSR }\end{array}$ & $\begin{array}{l}\text { Limitations in } \\
\text { extending bench } \\
\text { scale tests to full } \\
\text { scale }\end{array}$ \\
\hline
\end{tabular}


In testing of vegetation, there are several aspects that can be considered important, including plant age, size, physical arrangement, fire intensity, and time. Inconsistencies may occur in arranging the vegetation specimens in the calorimeter's holder (White et al. 2002). Therefore, proper measures should be introduced in arranging the vegetation specimen to ensure consistency. Concerning the radiative heat flux levels used for testing the vegetation fuel, some studies have used a constant heat flux level (Liu et al. 2013) throughout the test and some have used a gradient of heat flux in a range ( White et al. 2002, Fateh et al. 2016). One of the advantages of using low radiative heat flux is that it enhances the sensitivity of the test results to differences between the dry specimens of the various species. However, it increases the likelihood that some mass loss occurs before sufficient flaming for complete combustion of the pyrolysis products (Dibble et al. 2007).

These studies show that results of cone calorimeter experiments provide ample knowledge in understanding the fire behavior of vegetation. Therefore, by testing plant species in VGS using the cone calorimeter, one can obtain a number of essential fire properties of these plant species, including ignition time, heat release rate, effective heat of combustion, mass loss rate, smoke, and gaseous effluents, in understanding the ignition, pyrolysis, and fire propagation in VGS.

\section{METHODS}

Three plant species commonly used for VGS - namely, Hedera helix Lowe, Peperomia obtusifolia (L.) A.Dietr., and Aglaonema commutatum Schott (the cultivar Lady Valentine-were selected for study (Figure 1). The ignitability of these species was tested from their live stage to the totally dry stage using the cone calorimeter. Based on previous experience and preliminary studies, the time duration of the experiment was set to 75 days, which was the time required for total drying of the plants starting from the live stage. For testing, plant matter is placed on the sample holder, and the sample holder is fixed to the cone calorimeter in the horizontal orientation. Note that the cone calorimeter sample holder can be fixed in the vertical orientation as well, for studying convective fluxes. Plants were kept for natural drying (at $25^{\circ} \mathrm{C}, 60 \%$ relative humidity) without watering. The average values of the commonly used parameters for characterizing plants include plant height, branch diameter, leaf thickness, and density of the plant (Table 2). Equation 3 and Equation 4 were used to calculate specimen density and bulk density, respectively:

$$
\text { Density of specimen }(\rho)=\frac{M_{\text {spec }}}{V_{\text {spec }}},
$$

where $V_{\text {spec }}$ is the volume of the specimen, and,

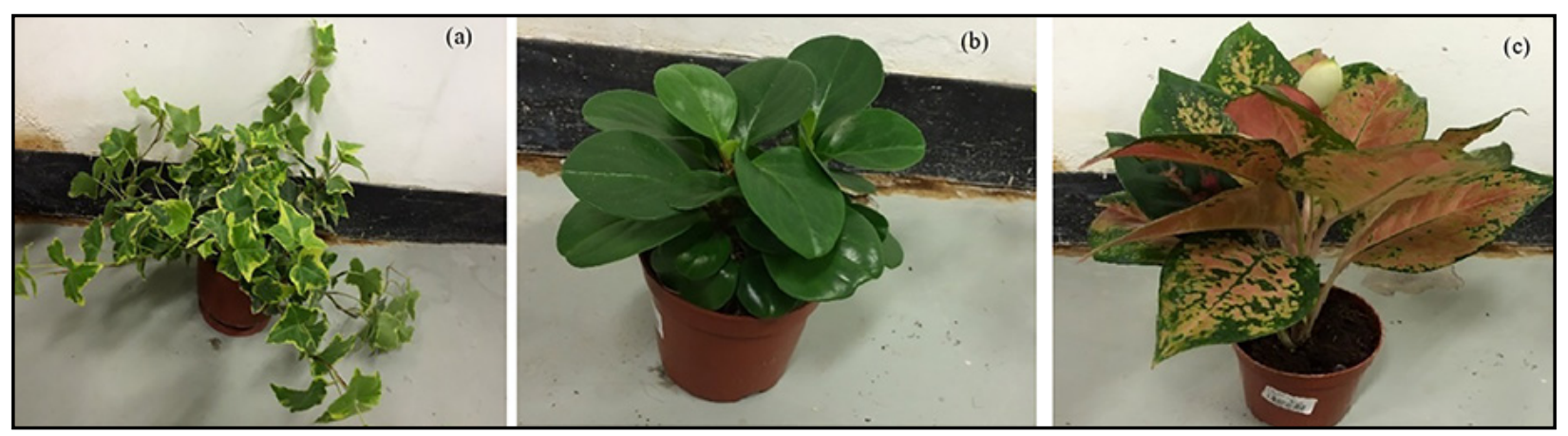

Figure 1. Plant species used for the experiment: (a) Hedera helix, (b) Peperomia obtusifolia, and (c) Aglaonema commutatum. 
Table 2. Average plant characteristics of the three plant species used for cone calorimeter testing.

\begin{tabular}{lccc}
\hline Parameters of plants & Hedera helix & Peperomia obtusifolia & Aglaonema commutatum \\
\hline Height $(\mathbf{m m})$ & 300 & 150 & 300 \\
\hline Branch diameter $(\mathbf{m m})$ & 20 & 60 & 90 \\
\hline Leaf thickness $(\mathbf{m m})$ & 1 & 3 & 1 \\
\hline Weight $(\mathbf{g})$ & 30 & 70 & 30 \\
\hline Density of specimen $\left(\mathbf{g ~ c m}^{-3}\right)$ & 0.1 & 0.08 & 0.08 \\
\hline Bulk density of specimen $\left(\mathbf{g ~ c m}^{-3}\right)$ & 0.3 & 0.7 & 0.3 \\
\hline
\end{tabular}

$$
\text { Bulk density of specimen }\left(\rho_{\mathrm{b}}\right)=\frac{M_{\text {spec }}}{V_{\text {holder }}}
$$

where $V_{\text {holder }}$ is the volume of the specimen holder. The volume of the specimen was measured by immersing a known mass of specimen in a known volume of water in a graduated cylinder and measuring the displacement of the fluid. In measuring the bulk density of the specimen, the volume of the specimen holder $(100 \mathrm{~mm} \times 100 \mathrm{~mm} \times 10 \mathrm{~mm})$ was taken to be equal to the specimen bulk volume. All plants were purchased from a local market and they were essentially free from dead materials.

An approximate amount of plant matter required to cover the surface area of the specimen holder was used in the test. Thus, the chosen weight for each fresh specimen was $20 \mathrm{~g}, 50 \mathrm{~g}$, and $20 \mathrm{~g}$ for Hedera helix, Peperomia obtusifolia, and Aglaonema commutatum, respectively. To ensure that a consistent amount of fuel was used for each test, on the first day of the experiment, all of the plants were removed from the soil and weighed into samples of $20 \mathrm{~g}$ each for Hedera helix and Aglaonema commutatum, and $50 \mathrm{~g}$ samples for Peperomia obtusifolia. The weighed samples were then stored separately for natural drying. Removal of the soil sped up the drying process of the plants. On the day of the test, each plant specimen was cut into pieces and placed in an aluminum foil container on the sample holder $(100 \mathrm{~mm} \times 100 \mathrm{~mm})$, lined with ceramic wool (Figure 2).

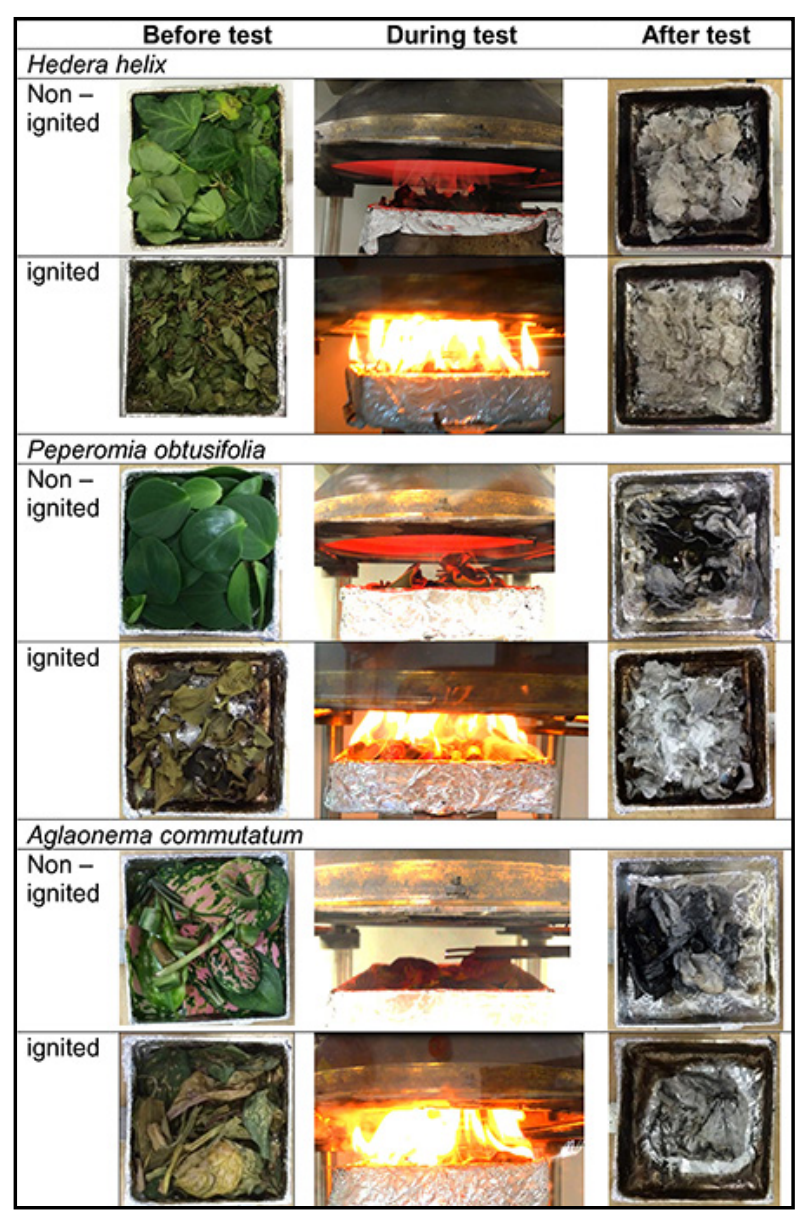

Figure 2. Test observations of non-ignited plant specimen and ignited plant specimens (radiative heat flux of $50 \mathrm{~kW} \mathrm{~m}^{-2}$ ).

Plant specimens were allowed to dry naturally and the MC of the specimens was measured at different times. Cone calorimeter testing was conducted for specimens with different MCs to study the impact of MC on igni- 
tion and other fire behaviors. Testing frequency was higher at the beginning of the experiment since the change of $\mathrm{MC}$ was more rapid then (Table 3). To calculate the specimen MC on each test date, one specimen of each species was oven dried at $70^{\circ} \mathrm{C}$ overnight, and the dry weight obtained. To study the impact of low and high radiant heat fluxes, testing was done under heat fluxes of $20 \mathrm{~kW} \mathrm{~m}^{-2}, 35 \mathrm{~kW}$ $\mathrm{m}^{-2}, 50 \mathrm{~kW} \mathrm{~m}^{-2}$, and $60 \mathrm{~kW} \mathrm{~m}^{-2}$. Parameters including heat release rate, peak heat release rate, ignition time, mass loss percentage, [CO], $\left[\mathrm{CO}_{2}\right]$, and smoke emissions were acquired for each test.

Table 3. Experimentation time schedule.

\begin{tabular}{cc}
\hline Day range of experiment & Testing frequency \\
\hline 1 to 5 & Each day \\
6 to 15 & Once every 2 days \\
16 to 30 & Once every 3 days \\
31 to 50 & Once every 4 days \\
50 to 75 & Once every 5 days \\
\hline
\end{tabular}

\section{RESULTS}

\section{Moisture Content}

The MC was calculated based on the dry weight as depicted in Equation 1 for one specimen on each test date. Among the species there was a considerable difference in the MC of live plants. Hedera helix had the lowest MC (326\%), whereas for Peperomia obtusifolia and Aglaonema commutatum, the MC was found to be $1371 \%$ and $1150 \%$, respectively. We measured the $\mathrm{MC}$ of each species during the testing period of 75 days (Figure 3 ). The drying process of Hedera helix was faster compared to the other two species, as is evident from the data. After approximately 20 days, the MC of Hedera helix became stable, which meant the plant had totally dried. The other two species showed lower rates of reduc-

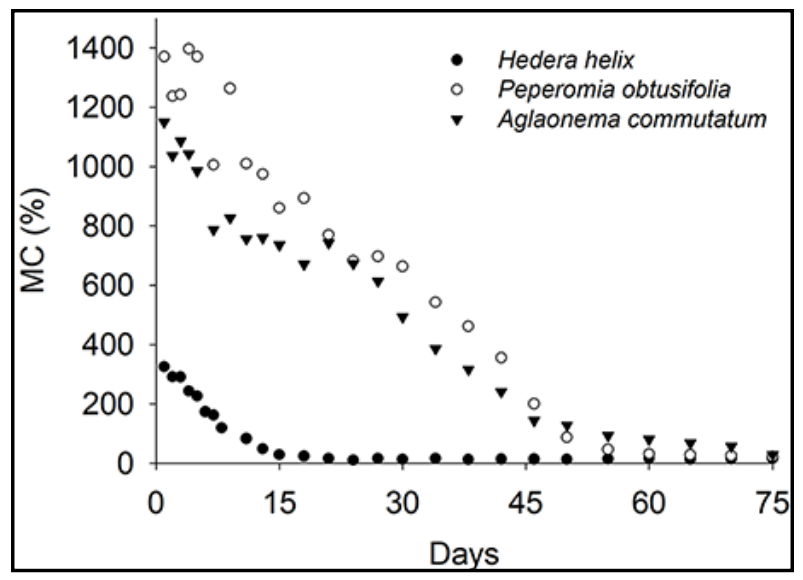

Figure 3. Variation of $\mathrm{MC}$ during drying process of plants.

tion in $\mathrm{MC}$ over the testing period and reached stable $\mathrm{MC}$ at or near the end of the experiment.

\section{Ignitability}

Fresh plant specimens of all three species did not ignite at any heat flux level in the test (from $20 \mathrm{~kW} \mathrm{~m}^{-2}$ to $60 \mathrm{~kW} \mathrm{~m}^{-2}$ ). The specimens started to ignite once their $\mathrm{MC}$ had reached a certain value (Figure 4). Hedera helix started to ignite at heat flux of $50 \mathrm{~kW} \mathrm{~m}^{-2}$, once the MC was lower than 243\%, 4 days after the start of the drying process. Peperomia obtusifolia started to ignite at heat flux of 20 $\mathrm{kW} \mathrm{m}^{-2}$ once the MC dropped below 200\%, 46 days after the start of the drying process. For Aglaonema commutatum, ignition occurred once the MC was lower than $316 \%$ at heat flux of $50 \mathrm{~kW} \mathrm{~m}^{-2}, 38$ days after the start of the drying process. Compared to the other two species, Hedera helix showed the higher tendency for drying quickly in absence of water. Dried Hedera helix had a higher risk of ignition when there was a heat source. The ignition time varied with the magnitude of radiative heat flux of the heat source. At higher radiative heat flux, the ignition time was low. We calculated the ignition time with respect to the $\mathrm{MC}$ of each species and non-ignition region for each species at different radiative heat flux- 


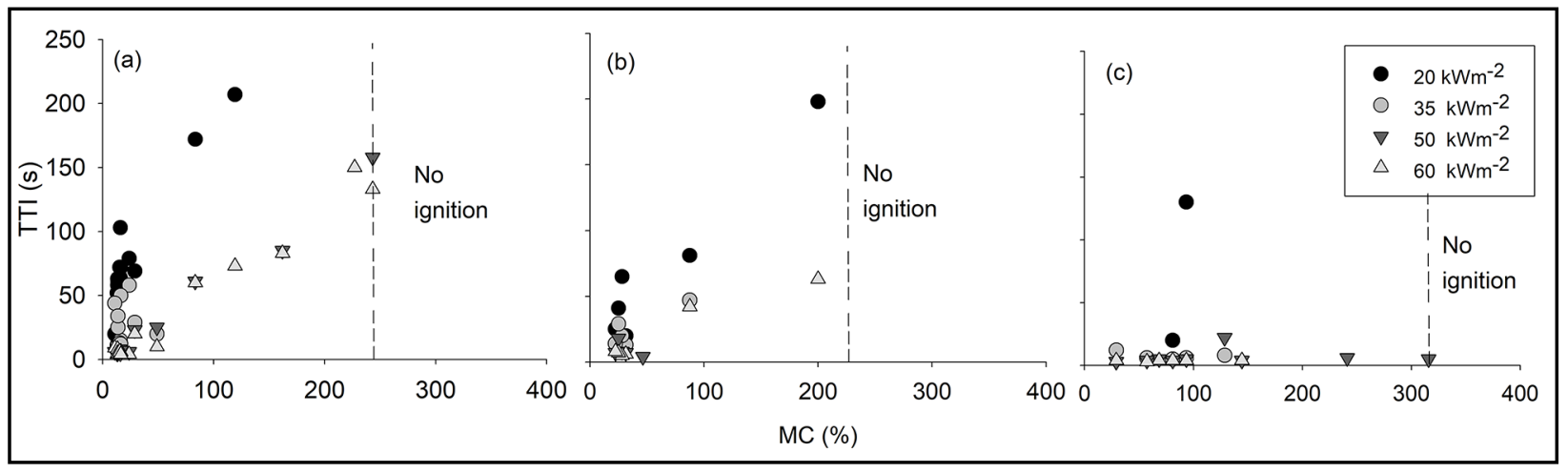

Figure 4. Ignition time (s) at different radiative heat fluxes for (a) Hedera helix, (b) Peperomia obtusifolia, and (c) Aglaonema commutatum.

es (Figure 4). Experimental studies showed that Mediterranean shrubs become very ignitable when $\mathrm{MC}$ is below $75 \%$ (Chuvieco et al. 2004). Dibble et al. (2007) tested 38 species from USA forests, using a cone calorimeter under $25 \mathrm{~kW} \mathrm{~m}^{-2}$ and observed that the ignition time varies from $15 \mathrm{~s}$ to $203 \mathrm{~s}$. Dimitrakopoulos and Papaioannou (2001) tested 48 different species of Mediterranean vegetation using a radiator cone heated up to $700{ }^{\circ} \mathrm{C}$ and showed that none of the species sustained fire when MC was higher than $140 \%$, and some of the less flammable species such as Platanus orientalis L. did not ignite until MC was around $40 \%$. In our case, we observed ignition when $\mathrm{MC}$ was less than $\sim 300 \%$, and the ignition time ranged from about $4 \mathrm{~s}$ to $200 \mathrm{~s}$. However, it should be noted that radiative heat fluxes directly affect the ignition and, at higher radiative heat flux, plant species may ignite at even higher MC levels.

These findings sufficiently prove that fresh and live plants hardly ignite even at higher radiative heat flux levels. However, when they start to dry and reach a lower MC, they will ignite when the $\mathrm{MC}$ has dropped below a certain value. The ignition time of a species depends on the MC and the imposed heat flux level. Our results are compatible with the findings of McAllister et al. (2012) on the ignition of live forest fuels. This study showed that ignition time increases when the fuel moisture content is high. However, the rela- tionship is not linear at all times (McAllister et al. 2012). Another experimental study (McAllister and Finney 2017) on ignition of fuel under convective and radiative heating showed that ignition time depends on the heat flux, which also agrees with our results. These results emphasize the importance of maintaining the VGS fresh and alive, and the choice of suitable plant species with a slow drying process. Poor maintenance, high amount of dead plant matter, and improper irrigation systems may reduce the overall MC of a VGS and increase risk of ignition when a heat source is present.

\section{Burning Behavior}

The transient heat release rate per unit area is one of the key thermal parameters in studying the burning behavior of materials. For all three species, transient heat release rate of fresh plants was not significant. However, when the MC decreases, there was a notable increase in transient heat release rate. Once the specimen started to ignite, drastic increase in transient heat release rate was observed. Soon after ignition, the whole specimen started to burn rapidly. When burning ceased, there was a drastic decrease in mass. In general, with the decrease of $\mathrm{MC}$, transient heat release rate, total heat release, and peak heat release rate tended to increase. We obtained the peak heat release rate values in relation to the 
$\mathrm{MC}$ at different radiative heat fluxes (Figure 5a). For Hedera helix, peak heat release rate increased from $3 \mathrm{~kW} \mathrm{~m}^{-2}$ to $200 \mathrm{~kW} \mathrm{~m}^{-2}$ with decrease in MC. For Peperomia obtusifolia, peak heat release rate increased from $1 \mathrm{~kW} \mathrm{~m}^{-2}$ to $202 \mathrm{~kW} \mathrm{~m}^{-2}$, and for Aglaonema commutatum, peak heat release rate increased from 3 $\mathrm{kW} \mathrm{m}{ }^{-2}$ to $121 \mathrm{~kW} \mathrm{~m}^{-2}$ with decrease in MC. These results show that the MC of a plant specimen essentially controls peak heat release rate, and total heat release. We calculated the average effective heat of combustion (in $\mathrm{MJ}$ $\mathrm{kg}^{-1}$ ) for each test specimen with respect to the $\mathrm{MC}$ of the specimen at different radiative heat fluxes (Figure 5b). Similar trends were observed for all three species, with average effective heat of combustion increasing as $\mathrm{MC}$ decreased. Plant species are too wet to ignite and burn completely at high MC. For parameters such as the peak heat release rate per unit area (pkHRR), the average effective heat of combustion (avgEHC), the peak emission of carbon dioxide (pk $\left[\mathrm{CO}_{2}\right]$ ), and the peak emission of carbon monoxide ( $\mathrm{pk}[\mathrm{CO}]$ ), curves can be fitted with respect to MC. The form of the fitted curve is represented in Equation 5, where $f$ represents the parameter, $f_{0}$ represents the value of the parameter at zero $\mathrm{MC}$, and $a$ denotes a constant:

$$
f=f_{0} \exp \left(\frac{-M C}{a}\right) .
$$

The correlation coefficients were high, from 0.88 to 0.91 , for the fitted curve of peak heat release rate per unit area with respect to $\mathrm{MC}$ for all plant species (Figure 5a). The correlation coefficients ranging from $\mathrm{R}^{2}=0.6$ to $\mathrm{R}^{2}=0.65$ showed that the exponential decay curves reasonably predicted the relationship among the average effective heat of combustion with MC (Figure 5b). This is because the plants burned more completely to give off more heat when MC was low. However, the correlation coefficients were not high for the fitted curves of the peak specific extinction area (Figure 6a) and peak smoke production rate (Figure 6b) with respect to $\mathrm{MC}$. This might be due to different plant species emitting more water vapor and generating different smoke characteristics while burning under different heat fluxes. The effect of MC on smoke emission will be investigated and reported in detail in our future work.

\section{Smoke and Gaseous Emissions}

We obtained the peak value of specific extinction area of smoke (in $\mathrm{m}^{2} \mathrm{~kg}^{-1}$ ) for each test

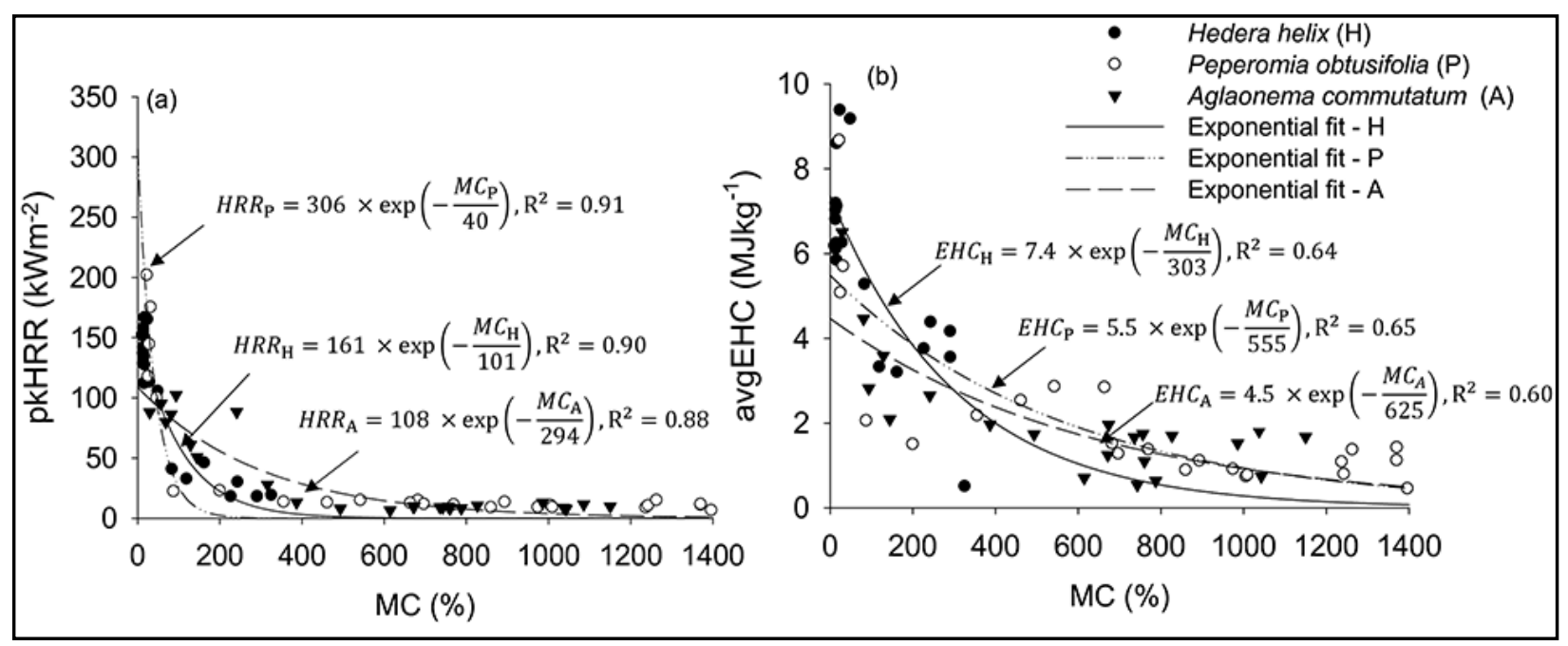

Figure 5. Thermal aspects of plants at radiative heat flux of $50 \mathrm{~kW} \mathrm{~m}^{-2}$. (a) Peak heat release rate per unit area (pk HRR; $\mathrm{kW} \mathrm{m}^{-2}$ ). (b) Average of effective heat of combustion (avgEHC; $\mathrm{MJ} \mathrm{kg}^{-2}$ ). 


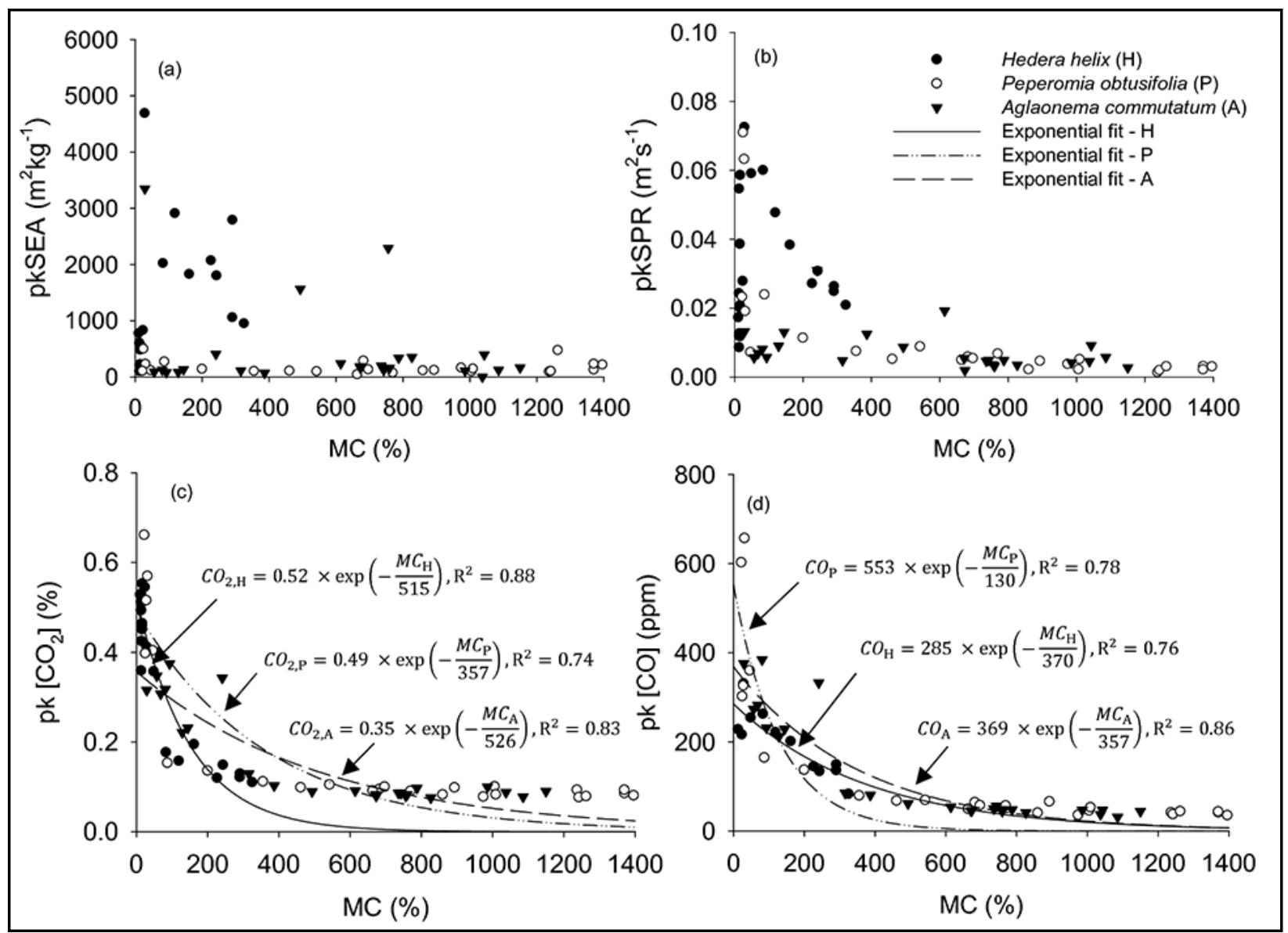

Figure 6. Smoke aspects of plants at radiative heat flux of $50 \mathrm{~kW} \mathrm{~m}^{-2}$. (a) Peak specific extinction area (pkSEA; $\left.\mathrm{m}^{2} \mathrm{~kg}^{-1}\right)$. (b) Peak smoke production rate (pkSPR; $\mathrm{m}^{2} \mathrm{~kg}^{-1}$ ). (c) Peak concentration of carbon dioxide (pk[CO2]; \%). (d) Peak concentration of carbon monoxide (pk[CO]; ppm)

(Figure 6a). The specific extinction area of Hedera helix was significantly higher compared to the other two species and increased with the decrease of MC. However, this trend was not significant for Peperomia obtusifolia or Aglaonema commutatum. We obtained the peak value of smoke production rate (in $\mathrm{m}^{2} \mathrm{~s}^{-1}$; Figure 6b). Hedera helix reached a higher rate of smoke production compared to the other species. Moreover, in all three species, smoke production rate increased when MC decreased. Smoke generated from vegetation fires is a complex mixture depending on the amount of cellulose, lignin, oils, and moisture of the vegetation. These results showed that Hedera helix behaved differently compared to the other two species. This is probably due to its thick waxy coating of the leaves. These waxes were vaporised while burning, producing more smoke. The presence of these flammable volatiles intensified the smoke.

We obtained the peak concentrations of carbon dioxide (in \%; Figure 6c) and carbon monoxide (in ppm; Figure 6d). The emission of both gaseous products increased at lower $\mathrm{MC}$. The highest emissions of $\left[\mathrm{CO}_{2}\right]$ and $[\mathrm{CO}]$ were recorded in the burning of Peperomia $o b$ tusifolia. These findings reveal the importance of selecting suitable species for VGS, in order to control its smoke toxin hazard and other gaseous emissions.

\section{Fire Risk}

In our study, three parameters were used to quantify the fire risks of the plant samples: 
flashover propensity (a stage in the development of a contained fire in which all exposed surfaces reach ignition temperatures more or less simultaneously and fire spreads rapidly throughout the space, denoted by $x$ in $\mathrm{kW} \mathrm{m}^{-2}$ $\mathrm{s}^{-1}$ ), total heat release (THR, denoted by $y$ in $\mathrm{MJ} \mathrm{m}^{-2}$ ), and smoke toxicity potency hazard (denoted by $z$ in $\mathrm{m}^{3} \mathrm{~kg}^{-1}$ ). As proposed by Petrella (1994), fire risk, based on the values of $x, y$, and $z$, is classified as very low risk, low risk, intermediate risk, high risk, and very high risk, with respect to flashover, thermal effects, or toxic hazards (Table 4).

Flashover propensity ( $x$, in $\mathrm{kW} \mathrm{m}^{-2} \mathrm{~s}^{-1}$ ). Flashover propensity is obtained using ignition time and peak heat release rate in Equation 6:

$$
x=\frac{p k H R R}{T T I}
$$

Risk of flashover can be classified based on this value (Table 4). At higher MC, specimens did not possess propensity for flashover since no ignition occurred. In all cases, once MC decreased, flashover propensity increased. In addition, risk of flashover propensity also increased with radiative heat fluxes (Figure 7a). Among the three species, risk of flashover of Hedera helix was slightly higher, comparatively. These observations show that drying of plants, higher radiative heat flux levels, and certain types of plant species would increase the risk of flashover propensity. These find- ings imply that VGS with healthy live plants has negligible propensity for flashover. However, when MC drops, it may create an intermediate risk of flashover, and eventually a high risk of flashover.

Total heat release $\left(y\right.$, in $\left.M J m^{-2}\right)$. The risk of thermal effect, denoted by $y$ (in $\mathrm{MJm}^{-2}$ ) is obtained through total heat release as depicted in Equation 7:

$$
y=T H R
$$

Lower MC levels create a higher risk of thermal effect (Figure 7b). Hedera helix has higher risk in terms of thermal effect compared to the other two species. However, test results show that, even at low MC and high radiative heat flux level, the thermal effect fell under the low risk category (Table 4).

Smoke toxicity potency hazard (z, in $\mathrm{m}^{3} \mathrm{~kg}^{-1}$ ). Parameter $z$ represents the toxicity of smoke. Toxicity potency can be used as a parameter to quantify the smoke toxicity potency hazard $(z$; Babrauskas 2000). Toxicity potency is expressed as the lethal concentration of the fire effluent emitted to produce death in $50 \%$ of test animals for specified exposure time $\left(\mathrm{LC}_{50}\right.$, in $\mathrm{g} \mathrm{m}^{-3}$; ISO 1996). $\mathrm{LC}_{50}$ for a combustion product can be calculated with Fractional Effective Exposure Dose (FED), the total volume of dispersed toxic gases $\left(\mathrm{V}\right.$, in $\left.\mathrm{m}^{3}\right)$, and mass loss of the combustion product $(\Delta \mathrm{m})$, as in Equation 8:

Table 4. Risk classification table for flashover propensity $(x)$, total heat release $(y)$, and smoke toxicity

\begin{tabular}{|c|c|c|c|c|c|}
\hline \multicolumn{2}{|c|}{$x\left(\mathrm{~kW} \mathrm{~m}^{-2} \mathrm{~s}^{-1}\right)$} & \multicolumn{2}{|c|}{$y\left(\mathrm{MJ} \mathrm{m}^{-2}\right)$} & \multicolumn{2}{|c|}{$z\left(\mathrm{~m}^{3} \mathrm{~kg}^{-1}\right)$} \\
\hline Classification & Range & Classification & Range & Classification & Range \\
\hline Low & 0.1 to 1.0 & Very low & 0.1 to 1.0 & Low & 0.0 to 1.0 \\
\hline Intermediate & 1.0 to 10 & Low & 1.0 to 10 & Intermediate & 1.0 to 10 \\
\hline \multirow[t]{2}{*}{ High } & 10 to 100 & Intermediate & 10 to 100 & High & 10 to 100 \\
\hline & & High & 100 to 1000 & Very high & $>100$ \\
\hline
\end{tabular}
potency hazard $(z)$. 


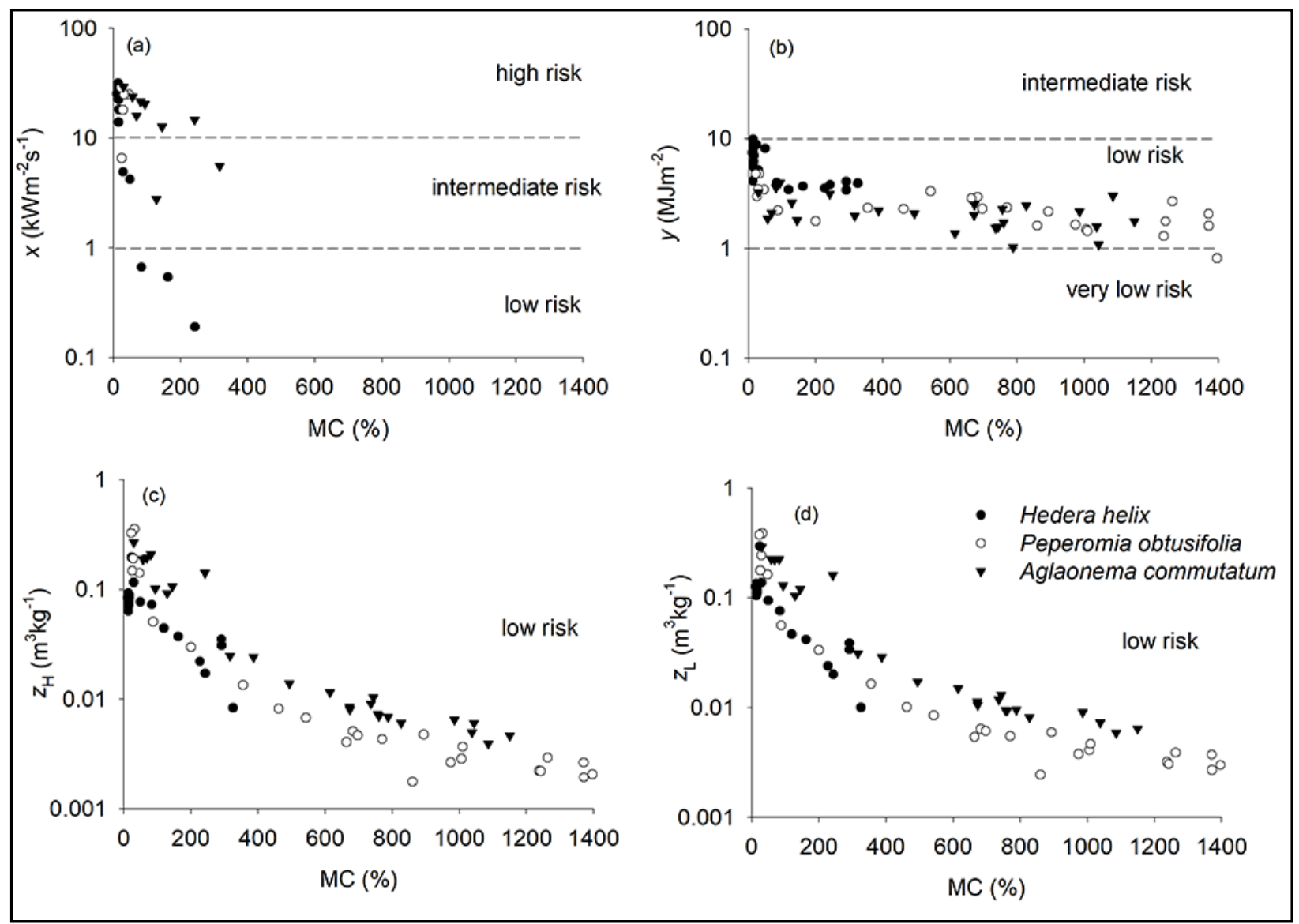

Figure 7. Risk parameters at radiative heat flux of $50 \mathrm{~kW} \mathrm{~m}^{-2}$ for (a) flashover propensity $\left(x ; \mathrm{kW} \mathrm{m}^{-2} \mathrm{~s}^{-1}\right)$, (b) total heat release $\left(y ; \mathrm{MJ} \mathrm{m}^{-2}\right)$, (c) higher level of smoke toxicity potency hazard $\left(z_{\mathrm{H}} ; \mathrm{m}^{3} \mathrm{~kg}^{-1}\right)$, and (d) lower level of smoke toxicity potency hazard $\left(z_{\mathrm{L}} ; \mathrm{m}^{3} \mathrm{~kg}^{-1}\right)$.

$$
L C_{50}=\frac{\Delta m}{F E D \times V}
$$

For cone calorimeter tests, $\mathrm{V}$ is considered to be $0.01 \mathrm{~m}^{3}$ and FED can be calculated based on $\mathrm{CO}_{2}$ and $\mathrm{CO}$ concentrations (Babrauskas 2000). The higher value of fractional effective exposure dose $\left(\mathrm{FED}_{\mathrm{H}}\right)$ and the lower value of fractional effective exposure dose $\left(\mathrm{FED}_{\mathrm{L}}\right)$ are calculated using the peak value of carbon monoxide (pk[CO], in ppm) and the peak value of carbon dioxide ( $\mathrm{pk}\left[\mathrm{CO}_{2}\right]$, in \%), respectively, as in Equation 9 and Equation 10 (Babrauskas 1997, 2000):

$$
F E D_{\mathrm{H}}=\frac{p k[C O]}{5000}
$$

$$
\text { and } F E D_{\mathrm{L}}=\frac{p k[\mathrm{CO}]}{5700}+\frac{p k\left[\mathrm{CO}_{2}\right]}{20} \text {. }
$$

The higher level $z_{\mathrm{H}}$ is obtained from $\mathrm{FED}_{\mathrm{H}}$, and the lower level $z_{\mathrm{L}}$ from $\mathrm{FED}_{\mathrm{L}}$, by using Equation 11 and Equation 12:

$$
z_{\mathrm{H}}=\frac{1000}{L C_{50 \mathrm{H}}}
$$

$$
\text { and } \quad z_{\mathrm{L}}=\frac{1000}{L C_{50 \mathrm{~L}}} \text {. }
$$

For all three species studied, we calculated values for higher level of smoke toxic hazard (Figure 7c) and lower level of smoke toxic 
hazard (Figure 7d). In general, higher and lower levels of smoke toxic hazard increased at low MC and high radiative heat flux levels. However, for all tested cases, both higher and lower levels of smoke toxic hazard fell under the low risk category (Table 4). Therefore, it can be pointed out that the three plant species tested in this study are unlikely to create a smoke toxicity potency hazard in case of a fire.

\section{Risk Classification}

The range of the $\mathrm{MC} \%$ of each risk matrix is decided to best represent the risk classification at each radiative heat flux levels. This analysis provides an overview on understand- ing the effect of radiative heat flux and MC for risk classification. We obtained the risk classification respectively for Hedera helix, Peperomia obtusifolia, and Aglaonema commutatum for each species at different MC ranges and heat flux levels (Table 5). At $20 \mathrm{~kW} \mathrm{~m}^{-2}$, none of the plant species have high risk of flashover. At $35 \mathrm{~kW} \mathrm{~m}^{-2}$, Hedera helix has high flashover risk once MC is below $\sim 13 \%$, whereas Peperomia obtusifolia has high flashover risk once the $\mathrm{MC}$ is below $\sim 25 \%$. At $50 \mathrm{~kW} \mathrm{~m}^{-2}$ and 60

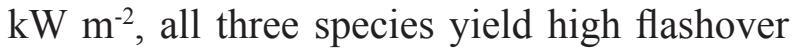
risk at lower MCs. These results support the idea that vegetation used for VGS only creates an intermediate risk for flashover if the radiative heat flux is lower than $20 \mathrm{~kW} \mathrm{~m}^{-2}$. How-

Table 5. Risk matrices for flashover propensity $(x)$, total heat release $(y)$, and smoke toxicity potency hazard $(z) . \mathrm{VL}=$ very low risk, $\mathrm{L}=$ low risk, $\mathrm{M}=$ intermediate risk, and $\mathrm{H}=$ high risk.

\begin{tabular}{|c|c|c|c|c|c|c|c|c|c|c|c|c|c|c|}
\hline \multicolumn{5}{|c|}{ Hedera helix } & \multicolumn{5}{|c|}{ Peperomia obtusifolia } & \multicolumn{5}{|c|}{ Aglaonema commutatum } \\
\hline \multicolumn{15}{|c|}{ (a) Flashover propensity $(x)$} \\
\hline \multirow{2}{*}{$\begin{array}{l}\text { MC } \\
(\%)\end{array}$} & \multicolumn{4}{|c|}{ Radiative heat flux $\left(\mathrm{kW} \mathrm{m}^{-2}\right)$} & \multirow{2}{*}{$\begin{array}{l}\mathrm{MC} \\
(\%)\end{array}$} & \multicolumn{4}{|c|}{ Radiative heat flux $\left(\mathrm{kW} \mathrm{m}^{-2}\right)$} & \multirow{2}{*}{$\begin{array}{l}\mathrm{MC} \\
(\%)\end{array}$} & \multicolumn{4}{|c|}{ Radiative heat flux $\left(\mathrm{kW} \mathrm{m}^{-2}\right)$} \\
\hline & 20 & 35 & 50 & 60 & & 20 & 35 & 50 & 60 & & 20 & 35 & 50 & 60 \\
\hline 51 to 350 & $\mathrm{~L}$ & $\mathrm{~L}$ & $\mathrm{~L}$ & $\mathrm{~L}$ & $\begin{array}{c}201 \text { to } \\
1400\end{array}$ & $\mathrm{~L}$ & $\mathrm{~L}$ & $\mathrm{~L}$ & $\mathrm{~L}$ & $\begin{array}{c}351 \text { to } \\
1200\end{array}$ & $\mathrm{~L}$ & $\mathrm{~L}$ & $\mathrm{~L}$ & $\mathrm{~L}$ \\
\hline 26 to 50 & $\mathrm{~L}$ & M & M & $\mathrm{H}$ & 51 to 200 & $\mathrm{~L}$ & $\mathrm{~L}$ & $\mathrm{~L}$ & L & $\begin{array}{c}151 \text { to } \\
350\end{array}$ & $\mathrm{~L}$ & $\mathrm{~L}$ & M & $\mathrm{H}$ \\
\hline 14 to 25 & M & $\mathrm{M}$ & $\mathrm{H}$ & $\mathrm{H}$ & 26 to 50 & M & $\mathrm{M}$ & $\mathrm{H}$ & $\mathrm{H}$ & $\begin{array}{c}29 \text { to } \\
150\end{array}$ & M & M & $\mathrm{H}$ & $\mathrm{H}$ \\
\hline 11 to 13 & $\mathrm{M}$ & $\mathrm{H}$ & $\mathrm{H}$ & $\mathrm{H}$ & 22 to 25 & M & $\mathrm{H}$ & $\mathrm{H}$ & $\mathrm{H}$ & & & & & \\
\hline
\end{tabular}

(b) Total heat release $(y)$

\begin{tabular}{|c|c|c|c|c|c|c|c|c|c|c|c|c|c|c|}
\hline \multirow{2}{*}{$\begin{array}{l}\mathrm{MC} \\
(\%)\end{array}$} & \multicolumn{4}{|c|}{ Radiative heat flux $\left(\mathrm{kW} \mathrm{m}^{-2}\right)$} & \multirow{2}{*}{$\begin{array}{l}\mathrm{MC} \\
(\%)\end{array}$} & \multicolumn{4}{|c|}{ Radiative heat flux $\left(\mathrm{kW} \mathrm{m}^{-2}\right)$} & \multirow{2}{*}{$\begin{array}{l}\mathrm{MC} \\
(\%)\end{array}$} & \multicolumn{4}{|c|}{ Radiative heat flux $\left(\mathrm{kW} \mathrm{m}^{-2}\right)$} \\
\hline & 20 & 35 & 50 & 60 & & 20 & 35 & 50 & 60 & & 20 & 35 & 50 & 60 \\
\hline $\begin{array}{c}250 \text { to } \\
350\end{array}$ & VL & $\mathrm{L}$ & $\mathrm{L}$ & $\mathrm{L}$ & $\begin{array}{c}1250 \text { to } \\
1400\end{array}$ & VL & VL & $\mathrm{L}$ & $\mathrm{L}$ & $\begin{array}{c}800 \text { to } \\
200\end{array}$ & VL & VL & $\mathrm{L}$ & $\mathrm{L}$ \\
\hline 11 to 250 & $\mathrm{~L}$ & $\mathrm{~L}$ & $\mathrm{~L}$ & $\mathrm{~L}$ & $\begin{array}{l}700 \text { to } \\
1250\end{array}$ & VL & $\mathrm{L}$ & $\mathrm{L}$ & $\mathrm{L}$ & $\begin{array}{l}650 \text { to } \\
800\end{array}$ & VL & $\mathrm{L}$ & $\mathrm{L}$ & $\mathrm{L}$ \\
\hline & & & & & 22 to 700 & $\mathrm{~L}$ & $\mathrm{~L}$ & $\mathrm{~L}$ & $\mathrm{~L}$ & $\begin{array}{c}29 \text { to } \\
650\end{array}$ & $\mathrm{~L}$ & $\mathrm{~L}$ & $\mathrm{~L}$ & $\mathrm{~L}$ \\
\hline
\end{tabular}

(c) Smoke toxicity potency hazard (z)

\begin{tabular}{|c|c|c|c|c|c|c|c|c|c|c|c|c|c|c|}
\hline \multirow{2}{*}{$\begin{array}{l}\mathrm{MC} \\
(\%)\end{array}$} & \multicolumn{4}{|c|}{ Radiative heat flux $\left(\mathrm{kW} \mathrm{m}^{-2}\right)$} & \multirow{2}{*}{$\begin{array}{l}\mathrm{MC} \\
(\%)\end{array}$} & \multicolumn{4}{|c|}{ Radiative heat flux $\left(\mathrm{kW} \mathrm{m}^{-2}\right)$} & \multirow{2}{*}{$\begin{array}{l}\text { MC } \\
(\%)\end{array}$} & \multicolumn{4}{|c|}{ Radiative heat flux $\left(\mathrm{kW} \mathrm{m}^{-2}\right)$} \\
\hline & 20 & 35 & 50 & 60 & & 20 & 35 & 50 & 60 & & 20 & 35 & 50 & 60 \\
\hline $11 \mathrm{t}$ & L & L & $\mathrm{L}$ & L & & $\mathrm{L}$ & L & L & L & & L & L & L & $\mathrm{L}$ \\
\hline
\end{tabular}


ever, at higher radiative heat flux levels, vegetation creates a high risk for flashover (Table 5a). None of the plant species have a high thermal risk or intermediate thermal risk, even at higher heat flux levels. At $20 \mathrm{~kW} \mathrm{~m}^{-2}$, thermal risk was very low for all three plant species at higher MC levels. At $50 \mathrm{~kW} \mathrm{~m}^{-2}$ and 60 $\mathrm{kW} \mathrm{m} \mathrm{m}^{-2}$, thermal risk was low for all three plant species at all MC levels (Table 5b). The smoke toxicity potency hazard, for all scenarios, showed a very low risk (Table $5 \mathrm{c}$ ).

Risk analysis based on the $x, y$, and $z$ parameters clearly showed that risk tends to get higher at lower MC. This demonstrates the importance of proper maintenance of plant species in VGS to keep them fresh and alive. These results also indicate that VGS are fire safe if the plants are alive and fresh. However, at low MC levels, there is risk of ignition even at low heat flux levels. All three species present a high risk of flashover at low MC and high radiative heat flux levels. However, the risk of thermal effect is low, and the three plant species studied will not create a significant toxic smoke hazard in case of fire, as indicated by the values of the corresponding parameters $y$ and $z$.

\section{CONCLUSION}

This study aimed to evaluate the fire risk of three common species of vegetation in VGS - Hedera helix, Peperomia obtusifolia, and Aglaonema commutatum - at different $\mathrm{MC}$ and heat flux levels using the cone calorimeter. Plant specimens were kept for a period of 75 days without watering, allowing the plant specimens to dry naturally. The cone calorimeter testing was carried out throughout the drying process from fresh foliage to dry foliage. Radiative heat fluxes ranging from 20 $\mathrm{kW} \mathrm{m}{ }^{-2}$ to $60 \mathrm{~kW} \mathrm{~m}^{-2}$ were used for the tests. Ignition time, heat release rate, effective heat of combustion, specific extinction area, smoke production rate, $\left[\mathrm{CO}_{2}\right]$, and $[\mathrm{CO}]$ were the parameters obtained from the cone calorimeter testing. Fresh plant specimens of all three spe- cies did not ignite even at high radiative heat flux levels. On the other hand, at low MC, ignition was observed for all species even at low radiative heat flux levels. Hedera helix, Peperomia obtusifolia, and Aglaonema commutatum started to ignite once MC dropped below $119 \%, 200 \%$, and $93 \%$, respectively, at a heat flux of $20 \mathrm{~kW} \mathrm{~m}^{-2}$. The peak heat release rate notably increased with decrease of $\mathrm{MC}$ for all three plant species tested. The peak heat release rate was $19 \mathrm{~kW} \mathrm{~m}^{-2}, 11 \mathrm{~kW} \mathrm{~m}^{-2}$, and 10 $\mathrm{kW} \mathrm{m} \mathrm{m}^{-2}$ for fresh plant specimens of Hedera helix, Peperomia obtusifolia, and Aglaonema commutatum, respectively, at a heat flux of 50 $\mathrm{kW} \mathrm{m}^{-2}$. The peak heat release rate increased up to $167 \mathrm{~kW} \mathrm{~m}^{-2}, 202 \mathrm{~kW} \mathrm{~m}^{-2}$, and $102 \mathrm{~kW}$ $\mathrm{m}^{-2}$ for dry samples of Hedera helix, Peperomia obtusifolia, and Aglaonema commutatum, respectively, at a heat flux of $50 \mathrm{~kW} \mathrm{~m}^{-2}$. The emission of smoke and gaseous effluents, $\left[\mathrm{CO}_{2}\right]$, and $[\mathrm{CO}]$ also increased with the decrease of $\mathrm{MC}$ for all three plant species tested. The peak $\left[\mathrm{CO}_{2}\right]$ emission increased from $0.1 \%$ to $0.6 \%$ for Hedera helix with the decline of $\mathrm{MC}$ of the specimen. For Peperomia obtusifolia and Aglaonema commutatum, the peak $\left[\mathrm{CO}_{2}\right]$ emission of the dry specimen increased by $0.6 \%$ and $0.3 \%$, respectively, compared to the fresh specimen. The peak emission of [CO] increased by 180 ppm, 560 ppm, and 340 ppm for dried out specimens of Hedera helix, Peperomia obtusifolia, and Aglaonema commutatum, respectively, at a heat flux of $50 \mathrm{~kW}$ $\mathrm{m}^{-2}$. According to the risk classification for flashover propensity $x$, a low MC created a high risk for flashover at high radiative heat flux levels. At a radiative heat flux above 50 $\mathrm{kW} \mathrm{m} \mathrm{m}^{-2}$, all three species had high flashover risk at lower MC. The thermal effect (parameter $y$ ) also increased at low MC, but the thermal risk was not very significant in any scenario. When considering parameter $z$, which denotes the risk of smoke toxicity, results showed that $z_{\mathrm{H}}$ and $z_{\mathrm{L}}$ increased at low $\mathrm{MC}$, but the risk was very low for all cases.

The results of our study clearly indicate the importance of maintaining a healthy and 
live VGS in order to ensure minimum risk of fire. Inadequate irrigation or malfunctioning of the irrigation system would lead to drying of plants in VGS. In addition, the presence of considerable dead matter of plants due to poor maintenance may decrease the overall MC of plants. Moreover, different plant species may behave in distinctive manners under similar environmental conditions. Therefore, appropriate selection of plant species and adequate knowledge of these plant species are as im- portant as proper irrigation and maintenance. If a VGS consists of a wide range of plant species, it is important to understand fire behavior of each plant species, since different plant species may behave differently when subjected to fire. The results of our study also indicate that there is merit in using Hedera helix, Peperomia obtusifolia, and Aglaonema commutatum in a VGS, since the overall thermal effects and smoke toxic hazards are low for these plant species in the event of fire.

\section{ACKNOWLEDGEMENTS}

The work described in this paper was supported by the Hong Kong PhD Fellowship Scheme at the City University of Hong Kong; a General Research Fund from the Research Grants Council of the Hong Kong Special Administrative Region, China (Project No. 11274516); and a grant from City University of Hong Kong (Project No. 7004363).

\section{LITERATURE CITED}

ASTM [American Society for Testing and Materials]. 1997. ASTM E1678-97. Standard test method for measuring toxicity for use in fire hazard analysis. ASTM International, West Conshohocken, Pennsylvania, USA.

ASTM [American Society for Testing and Materials]. 2017. ASTM E1354-97. Standard test method for heat and visible smoke release rates from materials and products using an oxygen consumption calorimeter. ASTM International, West Conshohocken, Pennsylvania, USA

Babrauskas, V. 1997. Sandwich panel performance in full-scale and bench-scale fire tests. Fire and Materials 21(2): 53-65. doi: 10.1002/(SICI)1099-1018(199703)21:2<53::AID-FAM593 $>3.0 . \mathrm{CO} ; 2-8$

Babrauskas, V. 2000. Fire safety improvements in the combustion toxicity area: Is there a role for LC50 tests? Fire and Materials 24(2): 113-119. doi: 10.1002/1099-1018(200003/04)24:2<113::AID-FAM730>3.0.CO;2-L

Bertolin, M.L., M.F. Urretavizcaya, and G.E. Defossé. 2015. Fire emissions and carbon uptake in severely burned lenga beech (Nothofagus pumilio) forests of Patagonia, Argentina. Fire Ecology 11(1): 32-54. doi: 10.4996/fireecology.1101032

Brandwein, T. 2014. Fassadenbegrünung und Brände. <http://www.biotope-city.net/article/ fassadenbegr-nung-und-br-nde?page $=7>$. Accessed 5 November 2016. [In German.]

Buildings Department. 2011. Code of practice for fire safety in buildings. The Government of the Hong Kong Special Administrative Region, Hong Kong.

Chow, C.L., and W.K. Chow. 2003. Assessing fire safety provisions for satisfying green or sustainable building design criteria: Preliminary suggestions. International Journal on Architectural Science 4(3): 141-146.

Chow, C.L., W.K. Chow, and Z.A. Lu. 2004. Assessment of smoke toxicity of building materials. Pages 132-158 in: S. Lee, J. Kim, and E. Kim, editors. Proceedings of the 6th Asia-Oceania symposium on fire science and technology. International Association for Fire Safety Science, 17-20 March 2004, Daegu, Korea. 
Chow, C.L., S.S. Han, and X.M. Ni. 2016. A study on fire behaviour of combustible components of two commonly used photovoltaic panels. Fire and Materials 41(1): 65-83. doi: 10.1002/ fam. 2366

Chow, W.K. 2015. Performance-based approach to determining fire safety provisions for buildings in the Asia-Oceania regions. Building and Environment 91: 127-137. doi: 10.1016/j. buildenv.2015.04.007

Chuvieco, E., I. Aguado, and A.P. Dimitrakopoulos. 2004. Conversion of fuel moisture content values to ignition potential for integrated fire danger assessment. Canadian Journal of Forest Research 34(11): 2284-2293. doi: 10.1139/x04-101

Dahanayake, K.W.D.K.C., and C.L. Chow. 2015. A brief discussion on current vertical greenery systems in Hong Kong: the way forward. Pages 136-147 in: L. Rodrigues, editor. Proceedings of the 14th International Conference on Sustainable Energy Technologies (SET2015). World Society of Sustainable Energy Technologies, 25-27 August 2015, Nottingham, England, United Kingdom.

Dahanayake, K.W.D.K.C., and C.L. Chow. 2017. Studying the potential of energy saving through vertical greenery systems: Using EnergyPlus simulation program. Energy and Buildings 138: 47-59. doi: 10.1016/j.enbuild.2016.12.002

Department for Communities and Local Government London. 2013. Fire performance of green roofs and walls. <https://www.gov.uk/government/publications/fire-performance-of-greenroofs-and-walls $>$. Accessed 3 September 2016.

Dibble, A.C., R.H. White, and P.K. Lebow. 2007. Combustion characteristics of north-eastern USA vegetation tested in the cone calorimeter: invasive versus non-invasive plants. International Journal of Wildland Fire 16(4): 426-443. doi: 10.1071/WF05103

Dimitrakopoulos, A.P., and K.K. Papaioannou. 2001. Flammability assessment of Mediterranean forest fuels. Fire Technology 37(2): 143-152. doi: 10.1023/A:1011641601076

Fateh, T., F. Richard, B. Batiot, T. Rogaume, J. Luche, and J. Zaida. 2016. Characterization of the burning behavior and gaseous emissions of pine needles in a cone calorimeter-FTIR apparatus. Fire Safety Journal 82: 91-100. doi: 10.1016/j.firesaf.2016.03.008

Graham, J.B., and B.C. McCarthy. 2006. Effects of fine fuel moisture and loading on small scale fire behavior in mixed-oak forests of southeastern Ohio. Fire Ecology 2(1): 100-114. doi: 10.4996/fireecology.0201100

ISO [International Organization for Standardization]. 1993. ISO 5660-1: 1993. Fire tests on building materials and structures - part 15: method for measuring the rate of heat release of products. ISO, Geneva, Switzerland.

ISO [International Organization for Standardization]. 1996. ISO 13344: 1996(E). Determination of the lethal toxic potency of fire effluents. ISO, Geneva, Switzerland.

Jurdao, S., E. Chuvieco, and J.M. Arevalillo. 2012. Modelling fire ignition probability from satellite estimates of live fuel moisture content. Fire Ecology 8(1): 77-97. doi: 10.4996/ fireecology.0801077

Knez, N. 2014. Reaction to fire of green facades and roofs. <http://www.cstc.be/homepage/ download.cfm?dtype $=$ services\&doc $=05$ _Knez_ZAG_prezentacija_ENBRI_2014_v2.pdf\&lang=en $>$. Accessed 4 July 2016.

Lau, D., Q. Qiu, A. Zhou, and C. L. Chow. 2016. Long term performance and fire safety aspect of FRP composites used in building structures. Construction and Building Materials 126: 573-585. doi: 10.1016/j.conbuildmat.2016.09.031

Liu, M.H., L.T. Yi, S.Q. Yu, G.M. Zhou, H. Jiang, and X.P. Li. 2013. Combustibility of fresh leaves of 26 forest species in China. Journal of Tropical Forest Science 25(4): 528-536. 
Livingston, A.C., and J.M. Varner. 2016. Fuel moisture differences in a mixed native and non-native grassland: implications for fire regimes. Fire Ecology 12(1): 73-87. doi: 10.4996/ fireecology.1201073

McAllister, S., I. Grenfell, A. Hadlow, W.M. Jolly, M. Finney, and J. Cohen. 2012. Piloted ignition of live forest fuels. Fire Safety Journal 51: 133-142. doi: 10.1016/j.firesaf.2012.04.001

McAllister, S., and M. Finney. 2017. Autoignition of wood under combined convective and radiative heating. Proceedings of the Combustion Institute 36(2): 3073-3080. doi: 10.1016/j. proci.2016.06.110

McNeilage, A. 2012. Green walls 'need building code' to reduce fire hazard. <http://www.smh. com.au/nsw/green-walls-need-building-code-to-reduce-fire-hazard -20120914-25xf1.html>. Accessed 5 October 2016.

Morakinyo, T.E., K.W.D.K.C. Dahanayake, E. Ng, and C.L. Chow. 2017. Temperature and cooling demand reduction by green-roof types in different climates and urban densities: a co-simulation parametric study. Energy and Buildings 145: 226-237. doi: 10.1016/j.enbuild. 2017.03.066

Nelson, R.M. 2001. Water relations of forest fuels. Academic Press, San Francisco, California, USA. doi: 10.1016/B978-012386660-8/50006-4

Petrella, R.V. 1994. The assessment of full-scale fire hazards from cone calorimeter data. Journal of Fire Sciences 12(1): 14-43. doi: 10.1177/073490419401200102

Purser, D.A. 2008. Toxicity assessment of combustion products. Pages 151-156 in: P.J. DiNenno, editor. Society of Fire Protection Engineers (SFPE) handbook of fire protection engineering. National Fire Protection Association, Quincy, Massachusetts, USA.

Qi, Y., P.E. Dennison, J. Spencer, and D. Riaño. 2012. Monitoring live fuel moisture using soil moisture and remote sensing proxies. Fire Ecology 8(3): 71-87. doi: 10.4996/fireecology. 0803071

Santoni, P.A., E. Romagnoli, N. Chiaramonti, and T. Barboni. 2015. Scale effects on the heat release rate, smoke production rate, and species yields for a vegetation bed. Journal of Fire Sciences 33(4): 290-319. doi: 10.1177/0734904115591176

Weise, D.R., R.H. White, H. Robert, F.C. Beall, and M. Etlinger. 2005. Use of the cone calorimeter to detect seasonal differences in selected combustion characteristics of ornamental vegetation. International Journal of Wildland Fire 14(3): 321-338. doi: 10.1071/WF04035

White, N., C. Highett, V. Australia, and M.D. Firesert. 2014. Fire hazards of exterior wall assemblies containing combustible components final report. Fire Protection and Research Foundation, Quincy, Massachusetts, USA.

White, R.H., D. DeMars, and M. Bishop. 1997. Flammability of Christmas trees and other vegetation. Pages 99-110 in: C.J. Hilado, editor. Proceedings of the 24th international conference on fire safety. Products Safety Corporation, 21-24 July 1997, Columbus, Ohio, USA.

White, R.H., D.R. Weise, K. Mackes, and A.C. Dibble. 2002. Cone calorimeter testing of vegetation: an update. Pages 1-12 in: C.J. Hilado, editor. Proceedings of the 35th international conference on fire safety. Products Safety Corporation, 22-24 July 2002, Sissonville, West Virginia, USA. 